EMBRYARIDDLE
Aeronautical University

SCHOLARLY COMMONS

\section{International Journal of Aviation,} Aeronautics, and Aerospace

\title{
Assessment of the Evolving Low-Cost Business Model for the Future Importance of U.S. Secondary Airports
}

\author{
Nurettin Dinler \\ Florida Institute of Technology, ndinler2016@my.fit.edu \\ William B. Rankin \\ Florida Institute of Technology, wrankin@fit.edu
}

Follow this and additional works at: https://commons.erau.edu/ijaaa

Part of the Business Administration, Management, and Operations Commons, and the Tourism and Travel Commons

\section{Scholarly Commons Citation}

Dinler, N., \& Rankin, W. B. (2018). Assessment of the Evolving Low-Cost Business Model for the Future Importance of U.S. Secondary Airports. International Journal of Aviation, Aeronautics, and Aerospace, 5(4). https://doi.org/10.15394/ijaaa.2018.1267

This Literature Review is brought to you for free and open access by the Journals at Scholarly Commons. It has been accepted for inclusion in International Journal of Aviation, Aeronautics, and Aerospace by an authorized administrator of Scholarly Commons. For more information, please contact commons@erau.edu. 


\section{Introduction}

The worldwide liberalization of the air transport market has profoundly changed trends in the aviation industry. A liberalized market resulted in a favorable environment for the emergence of low-cost carriers (LCCs) (Graham, 2013). The appearance of low-cost carriers is one of the revolutionary events in the aviation industry (Dziedzic \& Warnock-Smith, 2016) given that many airports serving LCCs have seen enormous growth rates in passengers after the emergence of such airlines (Graham, 2013). LCCs focus on services at secondary airports is assumed to be the most apparent feature of the LCC business model (Dobruszkes, Givoni \& Vowles, 2017). Nevertheless, Dziedzic and Warnock (2016) stated that nothing is fixed forever; carriers modify their strategies and business models to adapt to the conditions of the continually changing market.

According to Boeing (2017), traditional LCC tactics have recently been reformed due to customer expectations, regional differences, and intense competition between airlines. Recent publications also claimed that LCCs have increasingly used primary airports or expressed an interest in extending more affordable travel into long-haul markets (Choo \& Oum, 2013; Dobruszkes et al., 2017; Dziedzic \& Warnock-Smith, 2016; Fageda, Suau-Sanchez, \& Mason, 2015; Jimenez, Claro, de Sousa, \& de Neufville, 2017). In this regard, some LCCs, such as Southwest Airlines have already a strategy of connecting passengers between their flights at primary airports (Holloway, 2008). However, Doganis (2013) (as cited in Fageda et al., 2015), states that the point-to-point service should still be a basis of the low-cost business model, as connecting passengers entails several consequences that have pernicious influences for airline business competitiveness. These observations raised a question: Does a change in a LCC's business model affect LCCs' market share of passenger enplanements at secondary airports in a multi-airport system (MAS)?

Traditionally, LCCs follow a business model that concentrates passenger services at secondary airports. The purpose of this study was to examine what effect, if any, exists between LCCs' market share of passenger enplanements at secondary airports and their business models in a multi-airport system in the US between the years of 1997 through 2017. To analyze this effect, one airline (Southwest Airlines), and five secondary airports (William P. Hobby Airport (HOU) in Houston, TX; Hollywood Burbank Airport (BUR) in Burbank, CA; Ontario International Airport (ONT) in Ontario, CA; Oakland International Airport (OAK) in Oakland, CA, and San Jose International Airport (SJC) in San Jose, CA) were studied. The present study also conducted a comparative market share analysis of airline competitors that serve to the secondary airports above to assist in the 
understanding of the effects of LCC business model evolution on LCCs' competitors.

\section{Literature Review}

\section{Understanding the Developments in LCCs Industry}

In the past 20 years, the U.S aviation industry has changed for the following reasons: the mandates of new security policies by the U.S. federal government after the September 11, 2001, terrorist attacks, and the economic crisis resulting from the recessions of 2001, 2007, and 2009. These factors resulted in a decrease in the level of demand for air travel and caused additional costs for both airports and airlines, such as the costs of lengthened passenger travel times and substantial increases in the price of jet fuel. In response to this crisis, the U.S. aviation industry reduced its capacity, eliminated inefficient aircraft types, and increased revenue via new and expanded ancillary fees (Spitz, O'Connor, Mills, Carroll, \& Murray, 2015). For example, airlines introduced unbundling of services for checked baggage and meals served onboard, resulting in passing some of rising fuel costs on to passengers (Morrison, Bonnefoy, Hansman \& Sgouridis 2010). According to Spitz et al. (2015), these measures enabled the U.S industry to return to profitability over the last 10 years.

Also, the increasingly dominant low-cost business sector has pushed for cost savings and enhanced efficiency at every level of the aviation industry (Bentley, 2008). Today, the growth of the aviation industry has been attributed to the developments in the low-cost sector. Currently, there are nine LCCs operating in the United States: (a) Air Tran Airways, (b) Allegiant Air, (c) Frontier Airlines, (d) JetBlue Airways, (e) Southwest Airlines, (f) Spirit Airlines, (g) Sun Country Airlines, (h) ViaAir and (i) Virgin America (ICAO, 2017).

According to Doganis (2006), the secret of LCCs' success is the focusing of services at secondary and regional airports due to the low operational cost structures, runway availability, not having deal with congestion, and rapid servicing, enplaning and deplaning operations. Williams (2011), and Vasigh, Fleming, and Tacker (2013) also highlighted that regional and secondary airports are a vital part of the LCC model.

Nevertheless, recent publications suggest that LCCs have moved increasingly to primary airports or changed some characteristics of their business models (Boeing, 2017; Choo \& Oum, 2013; Dobruszkes et al., 2017; Dziedzic \& Warnock-Smith, 2016; Fageda et al., 2015; Jimenez et al., 2017). Recent developments in the LCC business model have raised the obvious question: What is the future importance of secondary airports for LCCs? 
The literature includes a series of studies focusing on developments in the LCC industry. For example, Bentley (2008), Diaconu and Popescu (2011), and Graham (2013) investigated LCCs' business trends based on the airline-airport relationship, whereas Abda, Belobaba, and Swelbar (2012) and Wiltshire (2017) examined LCCdriven impacts on airfares, passenger traffic, and airport competition. Strickland (2015) also addressed the current challenges and prospects of European secondary airports regarding the developments in the LCC industry. According to Strickland (2015), "The existence of many European secondary airports is fragile. They face structural challenges of limits to potential demand, strong seasonality and the impact of consolidation and changing business models in the airline industry" ( $p$. $35)$.

However, Dobruszkes et al. (2017) noted that the overall impacts of the evolving of the LCC business model remain unclear on smaller (secondary) airports. Also, as pointed out by Graham (2013), the geographic coverage of such studies is limited mostly to Europe. By understanding the impacts of the evolving LCC business model, it might be possible to understand the secondary airports' conditions in the United States.

\section{The Traditional LCC Business Model}

The LCC model was developed in the U.S airline industry by Pacific Southwest Airline (PSA) in 1970 and was implemented for the first time by the American domestic carrier Southwest Airlines, with the purpose of offering lower airfares to the air travelers in 1971 (Diaconu \& Popescu, 2011).

According to Doganis (2010), the essence of the LCC business model is to provide a basic no-frills product or service based on simple operations to minimize costs and maximize efficiency. Moving forward, Doganis stated that another core characteristic of the LCC business model is to generate new demand by offering very low fares and flying to destinations not previously served. The other core characteristics of the low-cost model were tabulated in Table 1. In the view of Gillen and Lall (2004), the majority of LCCs provide short-haul point-to-point services, which allows aircraft to have more take-offs and landings thereby spending less time on the ground. Lordan (2014) pointed out that point-to-point (PP) networks are designed for a lower probability of delays, lower demand for personnel, and more economical aircraft turn-a-round times. Lordan (2014) goes on to explain that a point-to-point (PP) system attracts many LCCs due to a substantial cost reduction in the network configuration. Nevertheless, according to Cento (2008), airlines do not usually implement a pure point-to-point configuration; a fair proportion of their routes are planned from a set of base airports at which the carriers operate from one or a few airports to main destinations. 
Table 1.

Low-Cost Business Model

(Simple Product)

\begin{tabular}{|c|c|}
\hline & (Simple Product) \\
\hline \multirow{3}{*}{ Fares } & Low, simple - one-way \\
\hline & Minimum restrictions \\
\hline & Fares rise nearer departure \\
\hline \multirow{3}{*}{ Distribution } & Avoid travel agents \\
\hline & Either online or call center \\
\hline & Ticketless \\
\hline \multirow{3}{*}{ In-flight } & Single class \\
\hline & High-density seating \\
\hline & No meals or free drinks \\
\hline & (Simple Operations) \\
\hline \multirow[b]{2}{*}{ Aircraft } & Single type - maximum two \\
\hline & High utilization (11 hours/day) \\
\hline \multirow{3}{*}{ Sectors } & Short -300 to 600 miles \\
\hline & Point-to-point \\
\hline & $\begin{array}{l}\text { No hubbing or connecting } \\
\text { flights }\end{array}$ \\
\hline \multirow[b]{2}{*}{ Airports } & Secondary or uncongested \\
\hline & 20-30-minute turnarounds \\
\hline \multirow{3}{*}{ Staff } & Competitive wages \\
\hline & Profit-sharing \\
\hline & High productivity \\
\hline
\end{tabular}

Source: (Doganis, 2010, p.135)

Cento (2008) explained that every low-cost airline does not need to implement all the core characteristics of the LCC business model. For instance, in 
2005 Air Berlin started the UK domestic services by the implementation of the huband-spoke operation.

\section{LCC Business Model Evolution}

According to Holloway (2008), the airline business models have been evolving rapidly due to factors, such as deregulation and liberalization, the internet, and advances in aircraft technologies. Diaconu and Popescu (2011) state that unstable economic conditions in today's aviation market have also stimulated change in airline business models. For example, Štimac, Vince, and Vidović (2012) argued that the economic crises have affected the airlines business models profoundly.

Another example of today's severe economic conditions in airline market is the existence of intense competition between traditional carriers and low-cost carriers, resulting in a growing number of mergers, acquisitions and different types of alliances (Acar \& Karabulak, 2015). To this end, it has been claimed that LCCs have changed some practices associated with their business model. Table 2 shows a comparison of low-cost carrier business model practices.

The change in the low-cost airline business model can take several forms. For example, Fageda et al., (2015) suggest that some LCCs are shifting two fundamental characteristics of the traditional LCC business model: fare unbundling and point-to-point network design. With the fare unbundling strategy, airlines individually charge for the meals onboard, checked baggage, and services previously including in the ticket price (Brueckner, Lee, Picard \& Singer, 2015). Unbundling product offerings allows customers to pay for only the services that they want (Boeing, 2017). Nevertheless, Fageda et al., (2015) claim that many lowcost carriers have currently launched a fare category system that allows different services that previously were sold as independent ancillary products to be bundled. In other words, the unbundling strategy has been converted into a bundling strategy. Fageda et al. also claim that bundling services allows airlines to have better control of the offerings they provide to the customer. 
Table 2.

A Comparison of Low-Cost Carrier Business Model

Practices

\begin{tabular}{|l|l|l|}
\hline & Old Business Model & New Business Model \\
\hline Airport Types & $\begin{array}{l}\text { Regional and/or Secondary } \\
\text { and/or primary }\end{array}$ & Primary and/or secondary \\
\hline Code sharing & No & Can provide code sharing \\
\hline $\begin{array}{l}\text { Connecting } \\
\text { flights } \\
\text { feeding } \\
\text { services }\end{array}$ & No & $\begin{array}{l}\text { Can provide connecting } \\
\text { flights }\end{array}$ \\
\hline $\begin{array}{l}\text { Long-haul } \\
\text { flights }\end{array}$ & No & Can be long-haul \\
\hline $\begin{array}{l}\text { Frequent flyer } \\
\text { benefits }\end{array}$ & No & $\begin{array}{l}\text { Can offer frequent flyer } \\
\text { programs }\end{array}$ \\
\hline Frills & No & Depending on fare bundle \\
\hline Aircraft Type & Single type - Narrow body & $\begin{array}{l}\text { Single type or mix - Narrow } \\
\text { body and wide body }\end{array}$ \\
\hline
\end{tabular}

Source: (Fageda et al., 2015, p. 290)

Fageda et al. (2015) stress that although another critical principle of LCCs is short-haul point-to-point services, some LCCs have begun to connect some of their flights, feeding other airlines and making codeshare agreement (i.e., JetBlue code sharing with Emirates). According to de Wit and Zuidberg (2012), connecting flights can provide additional escapes from route density constraints for LCCs as well as an extra opportunity to attract additional traffic volume.

Another change in the LCC business model is associated with the increasing use of primary airports. According to Dziedzic and Warnock-Smith (2016) and Dobruszkes et al. (2017), LCCs focus on secondary airports is being challenged given that LCCs have used increasingly primary airports. The authors go on to explain that LCCs have become more interested in serving business passengers. Yet, de Wit and Zuidberg (2012) note that the secondary airports are not becoming attractive for time-sensitive business passengers due to the fact they are in remote 
areas, which is why LCCs have migrated from secondary airports to primary airports.

Also, some LCCs such as Norwegian Air Shuttle have introduced long-haul, low-cost flights in a point-to-point route structure and operate in thinner niche markets. (de Wit \& Zuidberg, 2012; Faegda et al., 2015). However, according to Holloway (2008), this is not a new business model because of People Express, an American low-cost airline. This airline operated from 1981 to 1987 in the long-haul market immediately after deregulation in 1978.

The other change in the LCC business model is that LCCs have provided frequent flier programs. Many LCCs in the United States provide frequent flier benefits to increase the partner related revenues (Sorensen, 2005). Some LCCs sell the frequent flyer points to program partners, such as car rental companies, hotel chains, and co-branded credit card companies to increase their ancillary revenues (de Wit \& Zuidberg, 2012).

Overall, the evolution of business models is the result of a decline in the organic growth of LCCs and the financial crisis in 2008 that forced LCCs to make a change in the business models (de Wit \& Zuidberg 2012; Fageda et al., 2015).

\section{Multi-airport Systems (MAS)}

Given the focus of this research on passenger enplanements at secondary airports within a multi-airport system (MAS), the specific literature on the multiairport systems was reviewed.

According to Bonnefoy (2008), a multi-airport system is "a set of two or more significant airports in a metropolitan region." (p. 27). Bonnefoy goes on to explain that the multi-airport systems have been used to help airport planners' decisions on airport development and planning and to predict the passenger traffic and demand. Also, de Neufville and Odoni (2013) define a multi-airport system as "the set of significant airports that serve commercial transport in a metropolitan region, without regard to ownership or political control of the individual airports" (p. 110). According to de Neufville and Odoni (2013), these definitions consist of some important points:

(a) they neglect military bases and general aviation fields;

(b) they refer to a metropolitan region instead of a city, which implies region may include several distinct cities; and

(c) the definitions do not pay attention to who owns the airport. 
Garriga (2003) also categorizes an airport system according to three different territorial morphologies: (a) archipelago, which is a territory with land mobility constraints; and it consists of a primary airport connecting the territory with main international nodes and a group of regional airports; (b) megapolis, which annually handles more than 50 million passengers and has more than 5 million inhabitants; and (c) regional, which is less concentrated areas that may possess large hinterlands but smoother urban settlements.

De Neufville and Odoni (2013) stress that a MAS presents one or more primary airports with the most traffic and one or more secondary airports with between 10 and 50 percent of the traffic of the primary airport in all cities. For example, there remain two airports types in some world-class cities, such as London, New York, Tokyo, Seoul, and Osaka: one is a primary airport, congested and located near the city center, and the other is a secondary airport, not-socongested and located far from the city center (Takebayashi, 2012).

According to Garriga (2003), a secondary airport in a multi-airport system handles a small amount of air traffic, generally less than 6 million annual passengers. However, de Neufville and Odoni (2013) suggest the level of air traffic needed to maintain a secondary airport is not fixed and is likely to change over the coming generation.

\section{Secondary Airports}

While there is no unique definition of secondary airports, Graham (2013) stated that "secondary airports are considered as substitute or reliever airports that complement the primary airports of the principal towns or cities" (p. 69). In the view of de Neufville (2006), "a secondary airport for a metropolitan area refers to any airport that effectively serves and competes for passenger traffic from that larger conurbation" (p. 7). In the definition of Ashiabor and Wei (2012), secondary airports are considered as "airports close to hub airports" (p. 1). Beria, Laurino, and Postorino (2017) identify secondary airports as "under-utilized airports that complement a network of primary or major airports" (p. 365).

According to Bonnefoy (2005), the emergence of secondary airports in the U.S existed when primary airports encountered congestion problems, as a result of reaching the limit of their capacity. When comparing traffic at primary airports, traffic at secondary airports is more changeable, as their traffic falls rapidly when traffic returns to the primary airports during recessions and startup airlines that use secondary airports as a base collapse (de Neufville \& Odoni, 2013).

In the view of Gillen and Lall (2004), the inefficiency of primary airports might be a motivation for the success of secondary airports. Gillen and Lall explain that secondary airports can offer LCCs better conditions for aircraft operations, 
such as fast turn-around times and lower aeronautical fees because they can be more efficient than significant airports since they are less congested. However, Choo and Oum (2013) claim that over the last decade, this business model has changed with more and more LCCs shifting their operations to major airports. Choo and Oum exemplify that JetBlue's principal base is at New York JFK Airport, and Virgin America's principal base is at San Francisco International Airport.

According to Choo and Oum (2013), another salient example of LCCs shifting their operations is Southwest's presence at major airports such as Philadelphia, Pittsburgh, Denver, Atlanta, and San Francisco. Besides, research of the impacts of LCCs on the top 200 airports between 1990 and 2008 conducted by Abda et al., (2012) found that several primary U.S. airports experienced more LCC presence and market shares recently.

\section{The Relationship between LCCs and Secondary Airports}

Graham (2013) stresses there is a relationship based on mutual interests between LCCs and secondary airports, which both LCCs and secondary airports try to expand their market share. While airports have been attempting to adapt to LCC business models by providing the necessary facilities and services LCCs require, LCCs have tried to answer latent and unsatisfied travel demands of passengers, considering the threats of alternative transport modes such as high-speed rail (Rey, Myro, \& Galera, 2011).

The publications of Lin, Mak, and Wong (2013) and Jankiewicz and Huderek-Glapska (2016) revealed that there is a definite relationship between LCCs and secondary airports. Nevertheless, depending on the developments in the LCC business model, these recent publications suggest that secondary airports will be facing some challenges in the next years and will only sustain flights to less critical destinations (Dziedzic \& Warnock-Smith, 2016; Strickland, 2015). Choo and Oum (2013) also claim that LCCs in the United States have focused their attention on primary airports rather than secondary airports.

\section{The "Southwest Effect" in multi-airport systems (MAS)}

In the literature, many studies have analyzed the impact of LCCs based on the competitive landscape, including Southwest Airlines (Bachwich \& Wittman, 2017). However, there were not many studies on the effect of evolving LCC business models on secondary airports within a MAS in the U.S.

The term "Southwest Effect" is a well-known phenomenon within the multi-airport systems (Vovles, 2001). In 1993, the term, "Southwest Effect" was documented for the first time by the Department of Transportation (DOT) to refer to a decrease in average ticket price and an increase in passenger traffic after 
Southwest Airlines launched a new route (Silk, 2017). Southwest Airlines' development in Providence, Rhode Island in the late 1990s is a salient example of this phenomenon (de Neufville \& Odoni, 2013). In 1996, Southwest Airlines began serving in Providence, Rhode Island, located a convenient sixty miles from Boston's Logan International Airport (Cheung, 2004). In Southwest's just three years of service, the overall traffic at the T.F. Green Airport in Providence tripled. After a decade, this airport became a major second airport for the Boston metropolitan region (de Neufville \& Odoni, 2013). In this regard, the effect of the developments in LCC business models can be understood by examining the novelty of Southwest's business model (Field, 2016). It stands to reason that Southwest Airlines is responsible for establishing the business model for LCCs (Asahi \& Murakami, 2017). Field (2016) also states that beyond no-frills, Southwest Airlines is the pioneer of most traditional LCC tactics, such as a standardized type of aircraft and point-to-point network configuration relying on secondary airports.

However, according to Holloway (2008), Southwest Airlines acknowledged that it was forced to adopt the legacy carriers' business strategies in response to its poor financial performance in the winter of 2006-2007. For example, Southwest and WestJet, a Canadian low-cost airline, introduced plans to code-share in 2008 (Holloway, 2008). However, this is not Southwest Airlines' first code share agreement. Southwest Airlines and American Trans Air (ATA) agreed to make code-sharing arrangement in 2005, which intimately connected until 2008 when ATA filed for bankruptcy (McMullen \& Du, 2007). In this regard, Southwest Airlines' strategy of connecting passengers between its flights at primary airports can be considered as a condition for internal feeding (Holloway, 2008). However, Summers (2016) stresses that Southwest Airlines has negotiated new codeshare and interline agreements with international airlines, which allows long-haul passengers to transfer from domestic flights. According to Wensveen and Leick (2009), LCCs can form alliances for interlining and frequent flyer programs due to interactive marketing agreements.

Another fundamental change to Southwest Airlines' business model is that although Southwest Airlines followed the secondary airport strategy in an earlier stage of development, it is now shifting its business strategies to primary airports (De Wit \& Zuidberg, 2012). Moving forward, de Wit and Zuidberg (2012) suggest that Southwest Airlines will likely focus more on primary airports by acquiring AirTran. To this end, in 2013, Southwest Airlines commemorated its first year of operations from Atlanta International Airport, the world's busiest airport. This is a good example to observe the change in the secondary airport strategy (Dobruszkes et al., 2017). 
Consequently, LCCs including Southwest Airlines have adopted a new business model with significant impacts for their network's geography (Dobruszkes et al., 2017).

\section{Research Design and Approach}

The procedures to acquire data collection are discussed in this section. The study utilized a mixed methods design, both quantitative and qualitative were used to analyze the research question. As with most studies of passenger traffic in the United States, this study used data from the U.S. Department of Transportation's (DOT) Bureau of Transportation Statistics (BTS). T-100 "Air Carrier Traffic and Capacity Data by Non-Stop Segment and On-Flight Market" provided data on passenger enplanements at airports as well as air carriers' traffic shares. The proposed study consisted of a data collection of Southwest Airlines' yearly passenger enplanements volume at the secondary airports, namely HOU, BUR, ONT, OAK and SJC, between the years of 1997 and 2017. This study also used this dataset to calculate annual enplanements at the secondary airports. The specified period was separated into two-time periods: 1997 to 2006 (old business model), and 2008 to 2017 (new business model). The base year was selected as 2007 because that was the year that Southwest Airlines started transitioning to the new business model characteristics of legacy carriers, as pointed out by Holloway (2008).

The study, then, investigated if a change in the Southwest Airlines' business models (IV) affected Southwest Airlines' market share of passenger enplanements at the secondary airports (DV). Using the chi-square tests, it was possible to determine the effect between Southwest Airlines' business models and its market share of passenger enplanements at the secondary airports. In this context, Southwest Airlines' market share of passenger enplanements at the secondary airports was categorized into two groups, which include above mean (1) and below mean $(0)$.

The research question that needed to be answered to achieve this goal and its hypotheses were: What effect does the change in the low-cost carrier's business model have on LCCs' market share of passenger enplanements at secondary airports?

\section{Null Hypothesis}

H0: There is no difference between LCCs' market share of passenger enplanements under the old business model and their market share of passenger enplanements under the new business model. 


\section{Alternative Hypothesis}

H1: There is a difference between LCCs' market share of passenger enplanements under the old business model and their market share of passenger enplanements under the new business model.

The target population of this study was secondary airports within multiairport systems and low-cost carriers operating to such airports in the US. Table 3 demonstrates U.S. metropolitan regions with a multi-airport system. The accessible population for drawing a sample was one airline, and five secondary airports within a multi-airport system.

Table 3.

Metropolitan regions with a multi-airport system in the U.S.

\begin{tabular}{|c|c|c|c|c|}
\hline Met. Regions & $\begin{array}{l}\text { Multi- } \\
\text { airport } \\
\text { System }\end{array}$ & $\begin{array}{l}\text { Primary } \\
\text { Airports }\end{array}$ & $\begin{array}{l}\text { Secondary } \\
\text { Airports }\end{array}$ & LCCs \\
\hline New York & Yes & $\begin{array}{l}\text { John F Kennedy } \\
\text { Int. (JFK); } \\
\text { LaGuardia } \\
\text { Airport (LGA); } \\
\text { Newark Liberty } \\
\text { Int. (EWR) }\end{array}$ & $\begin{array}{l}\text { Long Island } \\
\text { MacArthur } \\
\text { Airport } \\
\text { (ISP) }\end{array}$ & $\begin{array}{l}\text { Southwest } \\
\text { Airlines }\end{array}$ \\
\hline Los Angeles & Yes & $\begin{array}{l}\text { Los Angeles Int. } \\
(\mathrm{LAX})\end{array}$ & $\begin{array}{l}\text { Hollywood } \\
\text { Burbank } \\
\text { Airport } \\
\text { (BUR); } \\
\text { John } \\
\text { Wayne } \\
\text { Airport } \\
\text { (SNA); } \\
\text { Ontario Int. } \\
\text { Airport } \\
\text { (ONT); } \\
\text { Long Beach } \\
\text { Airport } \\
\text { (LGB) }\end{array}$ & $\begin{array}{l}\text { Southwest } \\
\text { Airlines; } \\
\text { JetBlue } \\
\text { Airways; } \\
\text { Frontier } \\
\text { Airlines }\end{array}$ \\
\hline Washington & Yes & $\begin{array}{l}\text { Baltimore/Wash } \\
\text { Int. Thurgood }\end{array}$ & & \\
\hline
\end{tabular}




\begin{tabular}{|c|c|c|c|c|}
\hline & & $\begin{array}{l}\text { Marshall (BWI); } \\
\text { Ronald Reagan } \\
\text { Washington } \\
\text { National (DCA); } \\
\text { Washington } \\
\text { Dulles } \\
\text { Int. (IAD) }\end{array}$ & & \\
\hline Chicago & Yes & $\begin{array}{l}\text { Chicago O'Hare } \\
\text { Int. (ORD); } \\
\text { Chicago } \\
\text { Midway } \quad \text { Int. } \\
\text { (MDW) }\end{array}$ & & \\
\hline San Francisco & Yes & $\begin{array}{l}\text { San Francisco } \\
\text { Int. (SFO) }\end{array}$ & $\begin{array}{l}\text { Oakland } \\
\text { Int. Airport } \\
\text { (OAK); } \\
\text { Norman Y. } \\
\text { Mineta San } \\
\text { Jose Int. } \\
\text { Airport } \\
\text { (SJC) }\end{array}$ & $\begin{array}{l}\text { Southwest } \\
\text { Airlines; } \\
\text { JetBlue } \\
\text { Airways; } \\
\text { Allegiant } \\
\text { Airlines; } \\
\text { Sun Country } \\
\text { Airlines }\end{array}$ \\
\hline Miami & Yes & $\begin{array}{lr}\text { Miami Int. } & \text { IMIA); Fort } \\
\text { Lauderdale/Holl } \\
\text { ywood (FLL) }\end{array}$ & & \\
\hline $\begin{array}{l}\text { Dallas/ Fort } \\
\text { Worth }\end{array}$ & Yes & $\begin{array}{l}\text { Dallas-Fort } \\
\text { Worth } \\
\text { Int. (DFW) }\end{array}$ & $\begin{array}{l}\text { Dallas Love } \\
\text { Field } \\
(\mathrm{DAL})\end{array}$ & $\begin{array}{l}\text { Southwest } \\
\text { Airlines, Sun } \\
\text { County } \\
\text { Airlines; } \\
\text { Virgin } \\
\text { America }\end{array}$ \\
\hline Houston & Yes & $\begin{array}{l}\text { George Bush } \\
\text { Int./Houston } \\
\text { (IAH) }\end{array}$ & $\begin{array}{l}\text { William } \mathrm{P} . \\
\text { Hobby } \\
\text { Airport } \\
\text { (HOU) }\end{array}$ & $\begin{array}{l}\text { Southwest } \\
\text { Airlines; } \\
\text { JetBlue } \\
\text { Airways }\end{array}$ \\
\hline
\end{tabular}




\begin{tabular}{|c|c|c|c|c|}
\hline Boston & Yes & $\begin{array}{l}\text { General Edward } \\
\text { Lawrence } \\
\text { Logan } \\
\text { (BOS) }\end{array}$ & $\begin{array}{l}\text { Manchester } \\
\text {-Boston } \\
\text { Regional } \\
\text { Airport } \\
\text { (MHT); } \\
\text { Theodore } \\
\text { Francis } \\
\text { Green } \\
\text { Memorial } \\
\text { State } \\
\text { Airport } \\
\text { (PVD) }\end{array}$ & $\begin{array}{l}\text { Southwest } \\
\text { Airlines; } \\
\text { JetBlue } \\
\text { Airways }\end{array}$ \\
\hline
\end{tabular}

Source: (Bonnefoy, 2005; de Neufville \& Odoni, 2013)

The sample for the proposed study was selected by using purposive sampling strategy (non-probability sampling) from the U.S multi-airport system. In this regard, William P. Hobby Airport (HOU) in Houston in the Houston multiairport system, Hollywood Burbank Airport (BUR) in Burbank; Ontario International Airport (ONT) in Ontario in the Los Angeles multi-airport system and Oakland International Airport (OAK); Norman Y. Mineta San Jose International Airport (SJC) in the San Francisco multi-airport system and Southwest Airlines were selected as a sample of the study, as it was believed that Southwest Airlines and the secondary airports above sufficiently represent the primary characteristics of the population and the phenomenon of Southwest effect. Table 4 demonstrates the Secondary Airports selected as a sample of study.

Table 4.

The Secondary Airports Selected as a Sample

\begin{tabular}{|l|l|l|l|l|}
\hline $\begin{array}{l}\text { Multi Airport } \\
\text { Systems }\end{array}$ & $\begin{array}{l}\text { Primary } \\
\text { Airports }\end{array}$ & $\begin{array}{l}\text { Year } \\
\text { of } \\
\text { entry }\end{array}$ & $\begin{array}{l}\text { Secondary } \\
\text { Airports }\end{array}$ & $\begin{array}{l}\text { Year } \\
\text { of } \\
\text { entry }\end{array}$ \\
\hline Houston & $\begin{array}{l}\text { George Bush } \\
\text { Intercontinental/ } \\
\text { Houston (IAH) }\end{array}$ & - & $\begin{array}{l}\text { William P. } \\
\text { Hobby Airport } \\
\text { (HOU) }\end{array}$ & 1971 \\
\hline San Francisco & San Francisco & 2007 & $\begin{array}{l}\text { Oakland Int. } \\
\text { Airport (OAK) }\end{array}$ & 1989 \\
& Int. (SFO) & & $\begin{array}{l}\text { Norman Y. } \\
\text { Mineta San Jose }\end{array}$ & \\
& & & $\begin{array}{l}\text { Int. Airport } \\
\text { (SJC) }\end{array}$ & 1993 \\
\hline
\end{tabular}




\begin{tabular}{|l|l|l|l|l|}
\hline & $\begin{array}{l}\text { Los Angeles Int. } \\
\text { Los Angeles }\end{array}$ & 1982 & $\begin{array}{l}\text { Ontario Int. } \\
\text { Airport (ONT) }\end{array}$ & 1985 \\
& & & $\begin{array}{l}\text { Hollywood } \\
\text { Airport (BUR) }\end{array}$ & \\
& & & & 1990 \\
\hline
\end{tabular}

Source: (Swamedia, 2017)

An appropriate sample size is vital for controlling the probability of making a Type II error (Michael, 2001). The first step in the process was to determine the number of degrees of freedom (Df). The number of degrees of freedom was found by using the following formula (Ary, Jacobs, Razavieh, \& Sorensen, 2010):

$$
\mathrm{df}=(\mathrm{C}-1)(\mathrm{R} 1)
$$

where $\quad \mathrm{df}=$ number of degrees of freedom,

$$
\begin{aligned}
& \mathrm{C}=\text { number of columns, } \\
& \mathrm{R}=\text { number of rows. }
\end{aligned}
$$

After determining the number of degrees of freedom, a post hoc power analysis was conducted considering these parameters- an $\alpha$ level $=.05, \mathrm{n}=100$, an effect size $=0.37$ and $\mathrm{Df}=1$.

For this study, there was one independent variable that had two categories: Southwest Airlines' old business model and new business model. In the context of the current study, the old business model refers to SWA's market share of passenger enplanements at the secondary airports between the years of 1997 and 2006. Also, the new business model refers to SWA's market share of passenger enplanements at the secondary airports between the years of 2008 to 2017. The year of 2007 was considered as an initial year of the new business strategies that are seen in SWA's business model. According to Holloway (2008), Southwest Airlines acknowledged that it was forced to adopt several of the legacy carriers' business strategies in response to its poor financial performance in the winter of 2006-2007.

The dependent variable in this study was SWA's market share of passenger enplanements at five secondary airports (William P. Hobby Airport (HOU) in Houston, TX; Hollywood Burbank Airport (BUR) in Burbank, CA; Ontario International Airport (ONT) in Ontario, CA; Oakland International Airport (OAK) in Oakland, CA and San Jose International Airport (SJC) in San Jose, CA). Southwest Airlines' market share at the secondary airports studied consists of origin and destination $(\mathrm{O} \& \mathrm{D})$ passengers boarding at the first or last points of a one-way itinerary. 


\section{Data Analysis}

This study used T-100 market data (Air Carrier Traffic and Capacity Data by Non-Stop Segment and On-Flight Market) derived from the Bureau of Transportation Statistics (BTS). The BTS have been administered to collect and disseminate transportation statistics every year since the DOT was established in 1966 (BTS, 2016). While generally coordinating DOT statistical programs, BTS compiles, analyzes, publishes, and archives data and information to satisfy the needs of decision makers, stakeholders, and scholars interested in air transportation. The need for a more proactive program of data collection and analysis of the DOT was approved and released by the White House in 1990 (BTS, 2016). This contributed to maintaining the validity and reliability of the data used in this study. The data used in this study was analyzed in two phases:

\section{Inferential Statistics}

In the first phase of the data analysis, inferential statistics was conducted by using the chi-square tests of significance. A chi-square test was considered to be an appropriate method for data analysis in this study, since the individual factors that represent the old and new business models could not be easily quantified and/or obtained. When dealing with categorical data for one dependent variable, the chisquare test (goodness of fit) is the appropriate test to use (Ary, Jacobs, Razavieh \& Sorensen, 2010).

The chi-square analysis was used to test the null hypothesis and determined if there was a significant difference between observed frequency of the airline's market share - above (1) or below (0) mean - and the expected frequency of LCC's market share while operating under the new or old business model.

By applying the following chi-square formula, it will be possible to determine if the difference between observed and expected frequencies is statistically significant (Ary et al., 2010).

$$
\chi 2=\Sigma[((\mathrm{fo}-\mathrm{f} \mathrm{e}) 2) /(\mathrm{f} \mathrm{e})]
$$

where

$$
\begin{aligned}
& \chi^{2}=\text { value of chi square } \\
& \text { fo }=\text { observed frequency } \\
& \text { fe }=\text { expected frequency }
\end{aligned}
$$


These analyses were conducted using JMP and the $\chi^{2}$ value obtained was reported for significance at $\alpha=.05$.

\section{Descriptive Statistics}

In the second stage of the data analysis, descriptive statistical analysis was conducted as follows:

a) summary statistics of the data used in this study;

b) socioeconomic and demographic factors in the secondary airport service areas; and

c) comparative market share analysis of SWA's primary competitors at the secondary airports pre-2007 and post-2007.

These statistics assisted in the interpretation of the data analyzed.

\section{Results}

This section provides an overview of the results, which were obtained in two phases. In phase one, a chi-square test was performed to examine what effect, if any, exists between the developments in SWA's business models and the SWA's market share of passenger enplanements at secondary airports in the U.S. between the years of 1997 and 2017. In phase two, a descriptive statistical analysis was used to complement the quantitative analysis and to visualize the results of the data collected. Graphical illustrations were used to assist the researcher in the interpretation of the data.

\section{Inferential Data Analyses}

The chi-square tested the null hypothesis to determine if there was a significant difference between the observed frequency of SWA's market share above (1) or below (0) mean- and the expected frequency of SWA's market share while operating under the new or old business model. The results of the analysis are illustrated in Figure 1. 


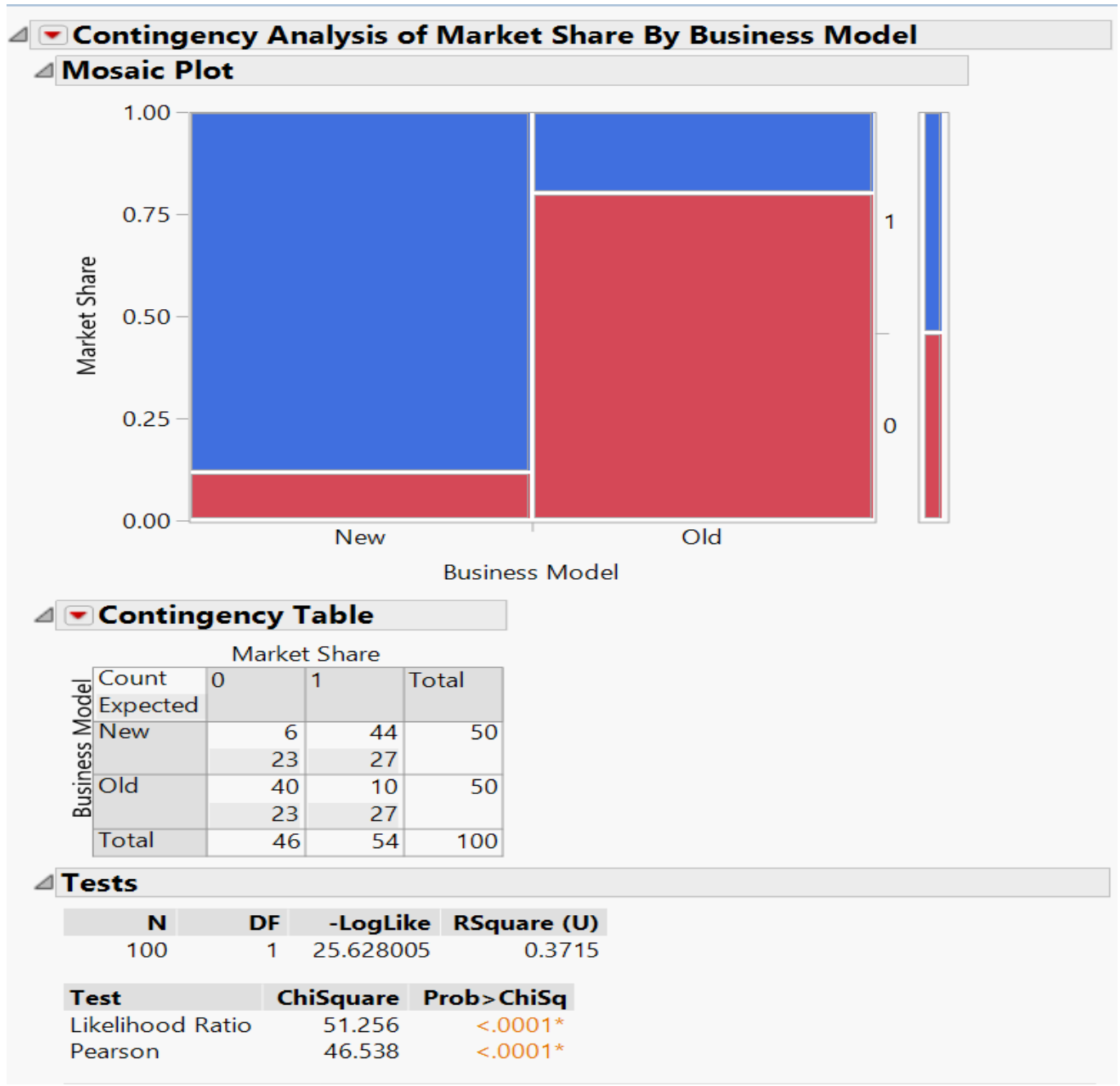

Figure 1: Chi-Square Test Results

As illustrated in Figure 1, the chi-square analysis indicates that the P-value (0.0001) is less than the significance level (0.05). Table 5 distinguishes between the observed frequency of the SWA's market share - below (0) or above (1) mean and the expected frequency of the SWA's market share while operating under the new or old business model. In this table, the observed frequency is the first number in each cell, whereas the expected frequency is the second number in each cell. As observed in Table 5, the number above the means (44) is higher than the number below the means (6) in the new business model category. Conversely, the number below the means (40) is higher than the number above the means (10) in the old business model category. If the change in the LCC business models did not affect 
LCCs' market share of passenger enplanements, the observed and expected frequency for each category in Table 5 would be the same.

\section{Table 5}

Contingency Table

\begin{tabular}{|l|l|l|l|}
\hline Observed & $\begin{array}{l}\text { Below Mean } \\
\text { Expected }\end{array}$ & $\begin{array}{l}\text { Above Mean } \\
(\mathbf{0})\end{array}$ & Total \\
\hline New & 6 & 44 & 50 \\
\hline Old & 23 & 27 & \\
\hline Total & 40 & 10 & 50 \\
\hline & 23 & 27 & 100 \\
\hline
\end{tabular}

\section{Descriptive Data Analysis}

The research used a sample size of $\mathrm{N}=100$ : where $\mathrm{n}=20$ for HOU, $\mathrm{n}=20$ for BUR, $\mathrm{n}=20$ for ONT, $\mathrm{n}=20$ for OAK, and $\mathrm{n}=20$ for SJC. Southwest Airlines' market share of passenger enplanements at each secondary airport from 1997 to 2017 was first used to describe the data in the study. To assist in the interpretation of the data, an analysis of socioeconomic and demographic factors and other airlines' market share in the same secondary service areas was included. The means of SWA's market share of passenger enplanements were tabulated and are shown in Table 6. The means of SWA's market share at secondary airports were distributed from a minimum of 43.61 (for SJC) to a maximum mean of 87.58 (for HOU). Standard deviations of SWA's market share ranged from 3.53 to 6.96 . 


\section{Table 6}

SWA's Market Share of Passenger Enplanements at Secondary Airports Ordered by Means Rating

\begin{tabular}{|l|l|l|l|l|l|}
\hline Secondary Airports & $\mathbf{n}$ & M & SD & Min & Max \\
\hline HOU & 20 & 87.58 & 3.53 & 80.46 & 93.4 \\
\hline BUR & 20 & 68.87 & 3.82 & 62.8 & 74.91 \\
\hline OAK & 20 & 67.11 & 4.70 & 57.99 & 74 \\
\hline ONT & 20 & 52.89 & 3.72 & 46.96 & 58.32 \\
\hline SJC & 20 & 43.61 & 6.96 & 33.61 & 52.93 \\
\hline
\end{tabular}

Figure 2 illustrates how SWA's market share at each secondary airport changed from 1997 to 2017. The data suggest that SWA's market share at each secondary airport followed a similar pattern over the period studied. Furthermore, in both 1997 and 2017, HOU was SWA's highest market share of passenger enplanements, while SJC was SWA's lowest market share of passenger enplanements. Overall, SWA's market share of passenger enplanements at each secondary airport saw a gradual increase from the years 1997 through 2017, as illustrated in Figure 2. 


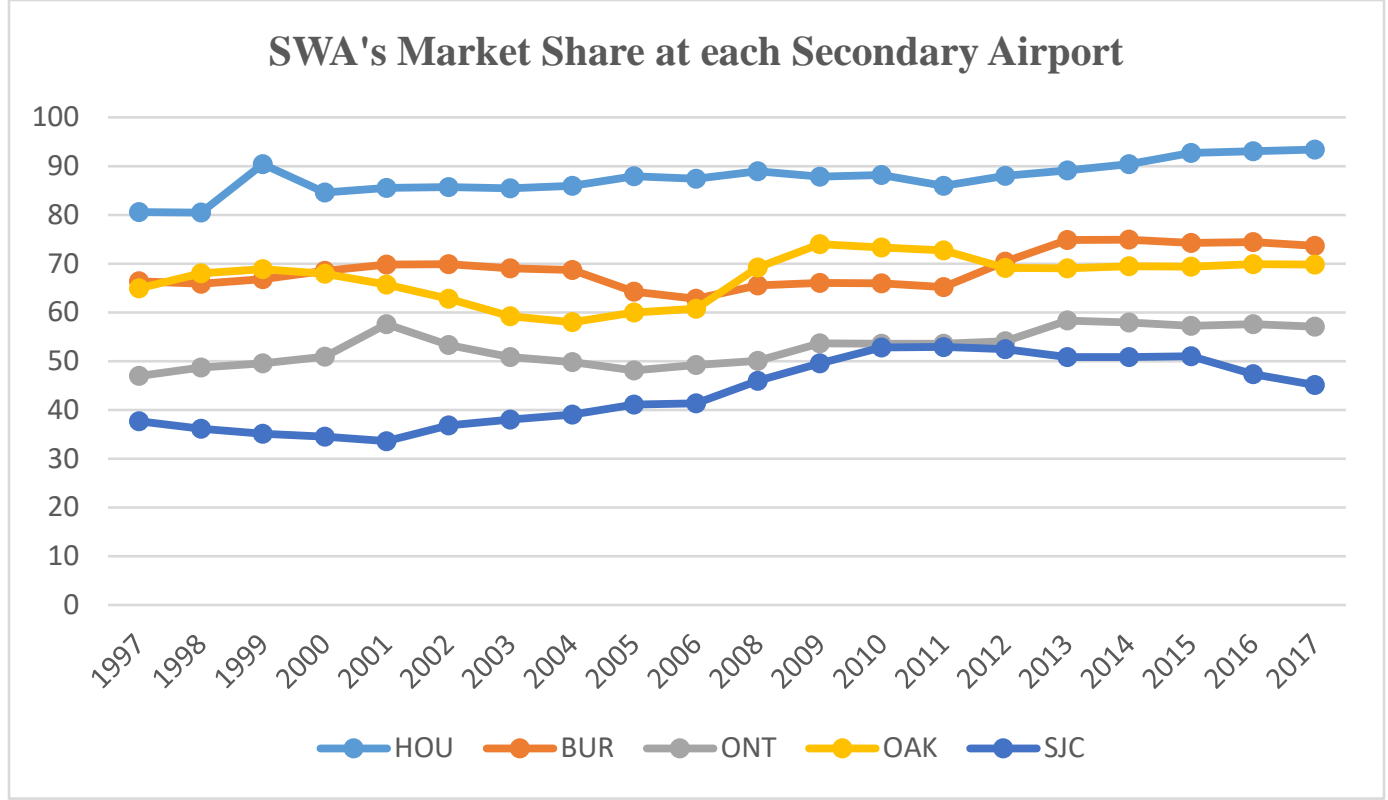

\section{Figure 2. SWA's Market Share of Passenger Enplanements}

Table 7 presents an overview of the summary statistics of SWA's passenger enplanements at the secondary airports from 1997 to 2017. As presented in Table10, SWA's annual passenger enplanements at secondary airports were distributed from a minimum mean of 1,412,384 (for ONT) to a maximum mean of 4,072,280 (for HOU).

\section{Table 7}

SWA's Passenger Enplanements at Secondary Airports Ordered by Mean Scores

\begin{tabular}{|l|l|l|l|l|l|}
\hline & n & M & SD & Min & Max \\
\hline HOU & 20 & $4,072,280$ & 915,785 & $3,156,956$ & $6,063,642$ \\
\hline OAK & 20 & $3,620,783$ & 409,190 & $2,832,679$ & $4,286,096$ \\
\hline SJC & 20 & $2,121,757$ & 218,291 & $1,782,783$ & $2,543,594$ \\
\hline BUR & 20 & $1,570,639$ & 114,785 & $1,394,618$ & $1,778,834$ \\
\hline ONT & 20 & $1,412,384$ & 208,424 & $1,142,105$ & $1,780,964$ \\
\hline
\end{tabular}

Figure 3 illustrates the number of SWA's passenger enplanements at each secondary airport in the year 1997 through 2017. As illustrated, the number of 
SWA's passenger enplanements at HOU, OAK, and SJC steadily increased, while the number of passengers enplaned at ONT and BUR did not change.

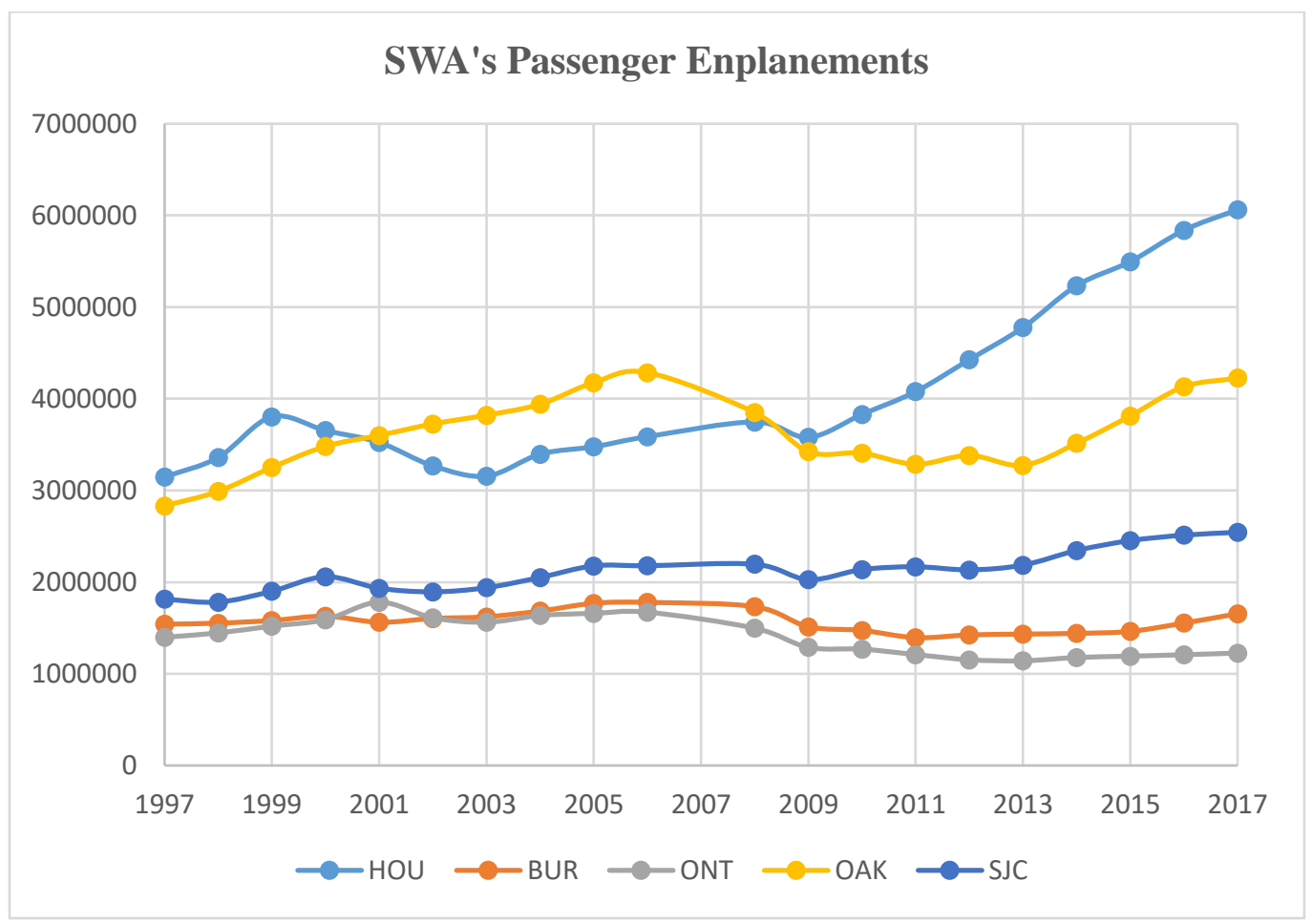

Figure 3. SWA's Passenger Enplanements at Secondary Airports

\section{Socioeconomic and Demographic Factors in the Service Areas of Secondary Airports}

Further analysis of socioeconomic and demographic factors was undertaken to understand the demand patterns in the service areas of secondary airports served by SWA over the period from 1997 to 2017. A graphical analysis was conducted considering SWA's employment rates, the U.S. personal income, and population statistics in the secondary airport service areas. Table 8 and Figure 4 provide data on the populations of five different cities in the service areas of secondary airports. 
Table 8

The Cities' Population in the Service Areas of Secondary Airports

\begin{tabular}{|c|c|c|c|c|c|}
\hline & $\begin{array}{l}\text { Houston, } \\
\text { TX }\end{array}$ & $\begin{array}{l}\text { Burbank, } \\
\text { CL }\end{array}$ & $\begin{array}{l}\text { Oakland, } \\
\text { CL }\end{array}$ & $\begin{array}{l}\text { Ontario, } \\
\text { CL }\end{array}$ & $\begin{array}{l}\text { San Jose, } \\
\text { CL }\end{array}$ \\
\hline 1997 & $1,807,000$ & 97,175 & 366,224 & 144,514 & 851,528 \\
\hline 1998 & $1,829,000$ & 98,139 & 365,762 & 146,385 & 862,637 \\
\hline 1999 & $1,846,000$ & 99,039 & 365,210 & 148,672 & 867,675 \\
\hline 2000 & $1,977,811$ & 100,468 & 400,674 & 158,664 & 903,540 \\
\hline 2001 & $1,994,316$ & 101,063 & 403,492 & 161,251 & 909,260 \\
\hline 2002 & $2,012,297$ & 101,965 & 400,564 & 163,857 & 900,840 \\
\hline 2003 & $2,032,955$ & 102,354 & 397,511 & 165,931 & 898,564 \\
\hline 2004 & $2,058,645$ & 102,710 & 394,433 & 168,068 & 901,283 \\
\hline 2005 & $2,076,189$ & 102,673 & 392,112 & 170,630 & 908,870 \\
\hline 2006 & $2,169,248$ & 102,275 & 392,076 & 170,865 & 918,619 \\
\hline 2007 & $2,206,573$ & 101,708 & 397,441 & 169,605 & 931,344 \\
\hline 2008 & $2,238,183$ & 102,031 & 403,188 & 170,947 & 948,686 \\
\hline 2009 & $2,257,926$ & 103,121 & 409,189 & 171,603 & 964,695 \\
\hline 2010 & $2,099,451$ & 103,340 & 390,724 & 163,924 & 945,942 \\
\hline 2011 & $2,126,196$ & 103,885 & 395,935 & 166,021 & 970,014 \\
\hline 2012 & $2,160,821$ & 104,391 & 400,740 & 167,211 & 982,765 \\
\hline 2013 & $2,195,914$ & 104,709 & 406,253 & 167,500 & 998,537 \\
\hline 2014 & $2,239,558$ & 105,368 & 413,775 & 169,089 & $1,015,785$ \\
\hline 2015 & $2,296,224$ & 105,319 & 419,267 & 171,214 & $1,026,908$ \\
\hline 2016 & $2,303,482$ & 104,447 & 420,005 & 173,212 & $1,025,350$ \\
\hline
\end{tabular}

Source: (Bureau of the Census ([BOC], 2017a) 


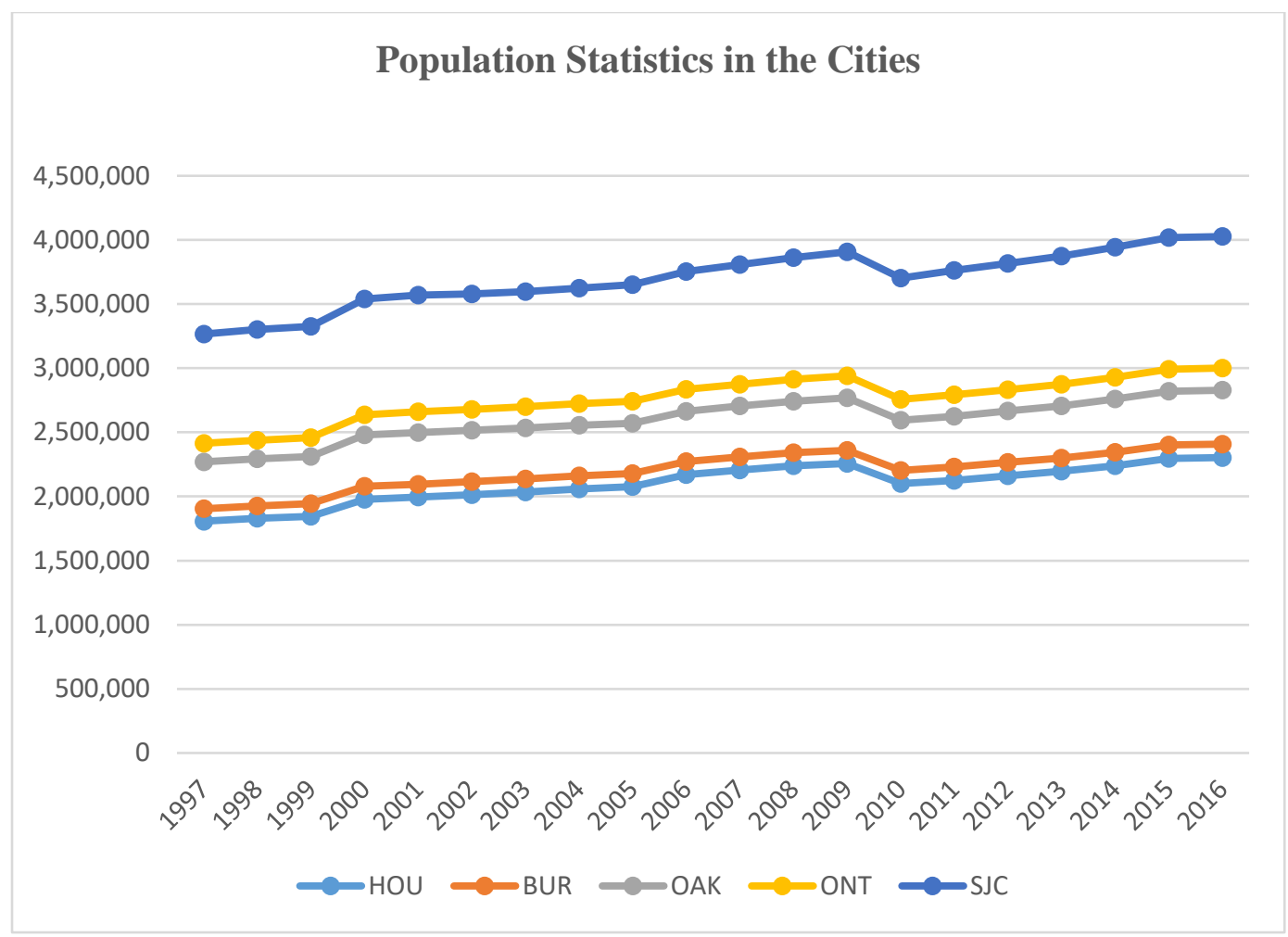

Figure 4. The Cities' Population in the Service Areas of Secondary Airports

As is illustrated, the population in secondary airports service areas increased steadily until 2009. This was followed by a downward trend during the years of 2010 and 2011. Overall, the population increased for all five cities in the secondary airport service areas from 1997 utill 2017. Table 9 and Figure 5 compare SWA's employment numbers and U.S. personal income over the period from 1997 through 2017. 


\section{Table 9}

\section{Socio-economic Factors}

\begin{tabular}{|c|c|c|}
\hline Years & SWA's Employment Numbers & The U.S. Personal Income \\
\hline 1997 & $290,135.00$ & $19,241.00$ \\
\hline 1998 & $301,282.00$ & $20,120.00$ \\
\hline 1999 & $328,438.00$ & $21,239.00$ \\
\hline 2000 & $344,075.00$ & $22,346.00$ \\
\hline 2001 & $370,699.00$ & $22,851.00$ \\
\hline 2002 & $401,038.00$ & $22,794.00$ \\
\hline 2003 & $400,581.00$ & $23,276.00$ \\
\hline 2004 & $380,110.00$ & $23,857.00$ \\
\hline 2005 & $378,507.00$ & $25,036.00$ \\
\hline 2006 & $386,007.00$ & $26,352.00$ \\
\hline 2008 & $420,095.00$ & $26,964.00$ \\
\hline 2009 & $425,483.00$ & $26,530.00$ \\
\hline 2010 & $421,197.00$ & $26,558.00$ \\
\hline 2011 & $441,483.00$ & $27,554.00$ \\
\hline 2012 & $537,581.00$ & $28,281.00$ \\
\hline 2013 & $552,149.00$ & $30,027.00$ \\
\hline 2014 & $555,250.00$ & $30,176.00$ \\
\hline 2015 & $585,521.00$ & $31,653.00$ \\
\hline 2016 & $637,015.00$ & $33,205.00$ \\
\hline
\end{tabular}

Source: (BOC, 2017b; BTS, 2017) 
The bar chart in Figure 5 illustrates the people employed by SWA from 1997 through 2017, while the line graph illustrates the U.S per capita income between 1997 and 2017. According to the data analyzed, the number of SWA's employees and the U.S. per capita income steadily increased from 1997 to 2017.

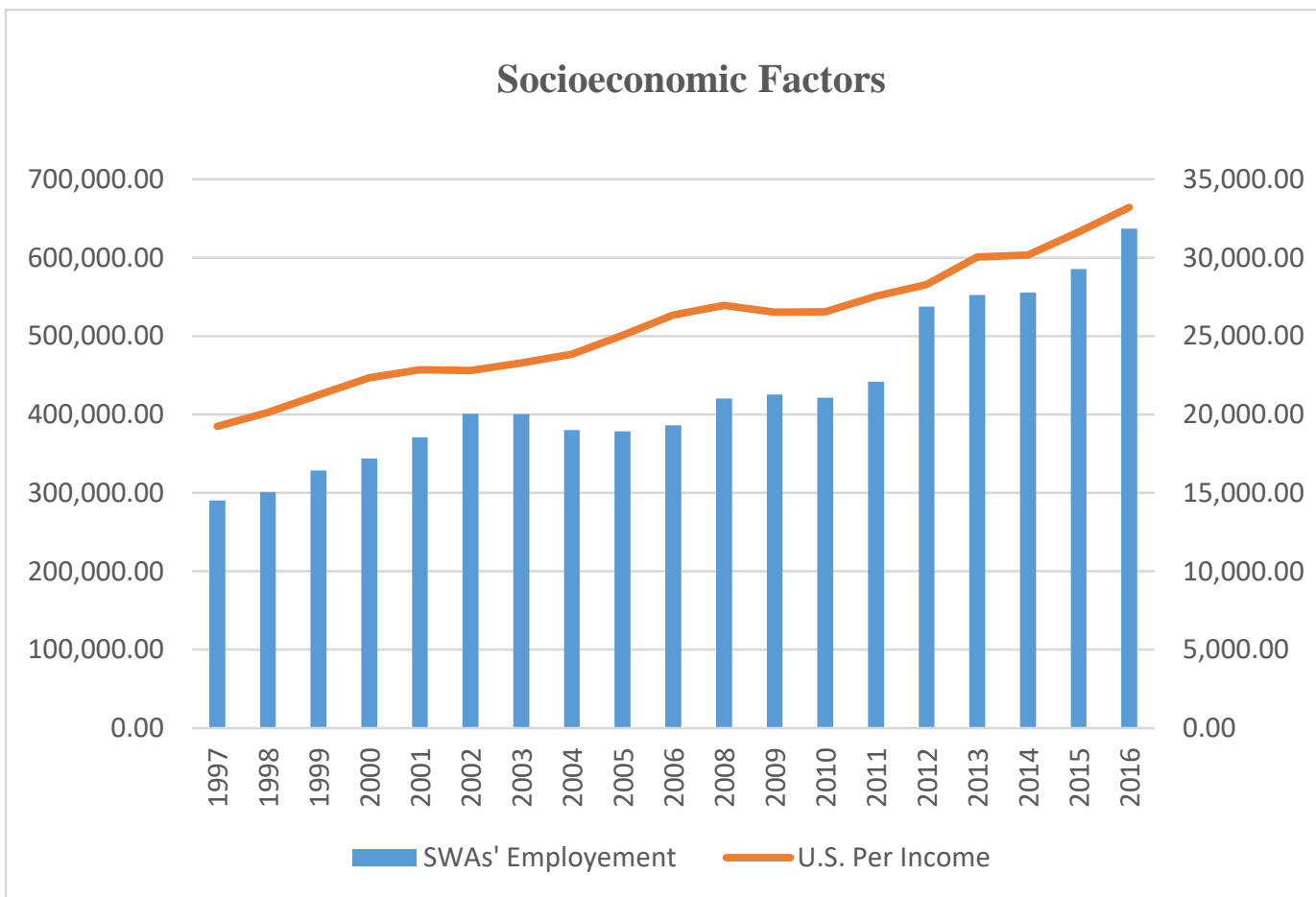

Figure 5. Socio-economic Factors

\section{Comparative Market Share Analysis of Passenger Enplanements}

A comparative market share analysis of airlines' passenger enplanements was undertaken to assist in the understanding of the effects that SWA's new business model had on competitors at the secondary airports from 1997 to 2017. An analysis of the data studied suggested that SWA's primary competitors in the secondary airport service areas served by SWA were determined to be Delta Airlines (DL) and American Airlines (AA). However, there were only two secondary airports in which all competitor airlines operated continuously from 1997 to 2017: San Jose International Airport (SJC) and Ontario International Airport (ONT). Therefore, it was determined that SJC and ONT would be the only secondary market service areas considered for a market share analysis of the airlines considered in this study. Figures 6 and 7 and Table 10 compare the airlines' market shares at ONT and SJC from the years 1997 through 2017. 
Table 10

The Airlines' Market Share Development at ONT and SJC between the years of 1997 and 2017

\begin{tabular}{|l|l|l|l|l|l|l|}
\hline & $\begin{array}{l}\text { Delta } \\
\text { (DL) }\end{array}$ & Airlines & $\begin{array}{l}\text { American } \\
\text { (AA) }\end{array}$ & Airlines & $\begin{array}{l}\text { Southwest } \\
\text { (SWA) }\end{array}$ & Airlines \\
\hline $\mathbf{1 9 9 7}$ & 9.08 & 4.76 & 6.19 & 12.67 & 46.96 & 37.71 \\
\hline $\mathbf{1 9 9 8}$ & 9.08 & 4.44 & 6.16 & 12.95 & 48.68 & 36.17 \\
\hline $\mathbf{1 9 9 9}$ & 8.30 & 4.31 & 6.06 & 18.06 & 49.57 & 35.11 \\
\hline $\mathbf{2 0 0 0}$ & 8.83 & 4.47 & 5.58 & 30.08 & 50.90 & 34.50 \\
\hline $\mathbf{2 0 0 1}$ & 8.38 & 4.66 & 5.62 & 30.65 & 57.56 & 33.61 \\
\hline $\mathbf{2 0 0 2}$ & 8.63 & 3.87 & 8.28 & 28.63 & 53.33 & 36.80 \\
\hline $\mathbf{2 0 0 3}$ & 6.50 & 3.63 & 6.92 & 19.80 & 50.82 & 38.03 \\
\hline $\mathbf{2 0 0 4}$ & 6.21 & 3.59 & 6.95 & 18.37 & 49.80 & 39.02 \\
\hline $\mathbf{2 0 0 5}$ & 8.42 & 3.72 & 7.05 & 13.96 & 48.09 & 41.06 \\
\hline $\mathbf{2 0 0 6}$ & 7.77 & 3.71 & 6.55 & 12.29 & 49.23 & 41.32 \\
\hline $\mathbf{2 0 0 8}$ & 5.18 & 2.75 & 6.86 & 9.89 & 50.08 & 46.01 \\
\hline $\mathbf{2 0 0 9}$ & 3.54 & 1.93 & 8.56 & 9.36 & 53.63 & 49.58 \\
\hline $\mathbf{2 0 1 0}$ & 3.74 & 3.63 & 8.87 & 8.65 & 53.54 & 52.84 \\
\hline $\mathbf{2 0 1 1}$ & 3.72 & 3.92 & 8.14 & 8.13 & 53.54 & 52.93 \\
\hline $\mathbf{2 0 1 2}$ & 3.50 & 3.42 & 8.29 & 7.05 & 54.10 & 52.47 \\
\hline $\mathbf{2 0 1 3}$ & 0.54 & 3.75 & 8.95 & 7.06 & 58.32 & 50.82 \\
\hline $\mathbf{2 0 1 4}$ & 1.42 & 3.44 & 9.88 & 6.72 & 57.97 & 50.87 \\
\hline $\mathbf{2 0 1 5}$ & 1.38 & 4.04 & 13.45 & 8.15 & 57.22 & 50.98 \\
\hline $\mathbf{2 0 1 6}$ & 1.56 & 6.79 & 15.98 & 9.95 & 57.55 & 47.33 \\
\hline & 1.41 & 7.33 & 16.64 & 8.66 & 57.05 & 45.12 \\
\hline
\end{tabular}


As illustrated in Figure 6, SWA and DL's market shares increased at SJC, whereas AA's market shares decreased. An opposite trend can be observed for the market shares of SWA and AA. After 2001, SWA market share steadily increased, while AA's market share saw a steady decrease.

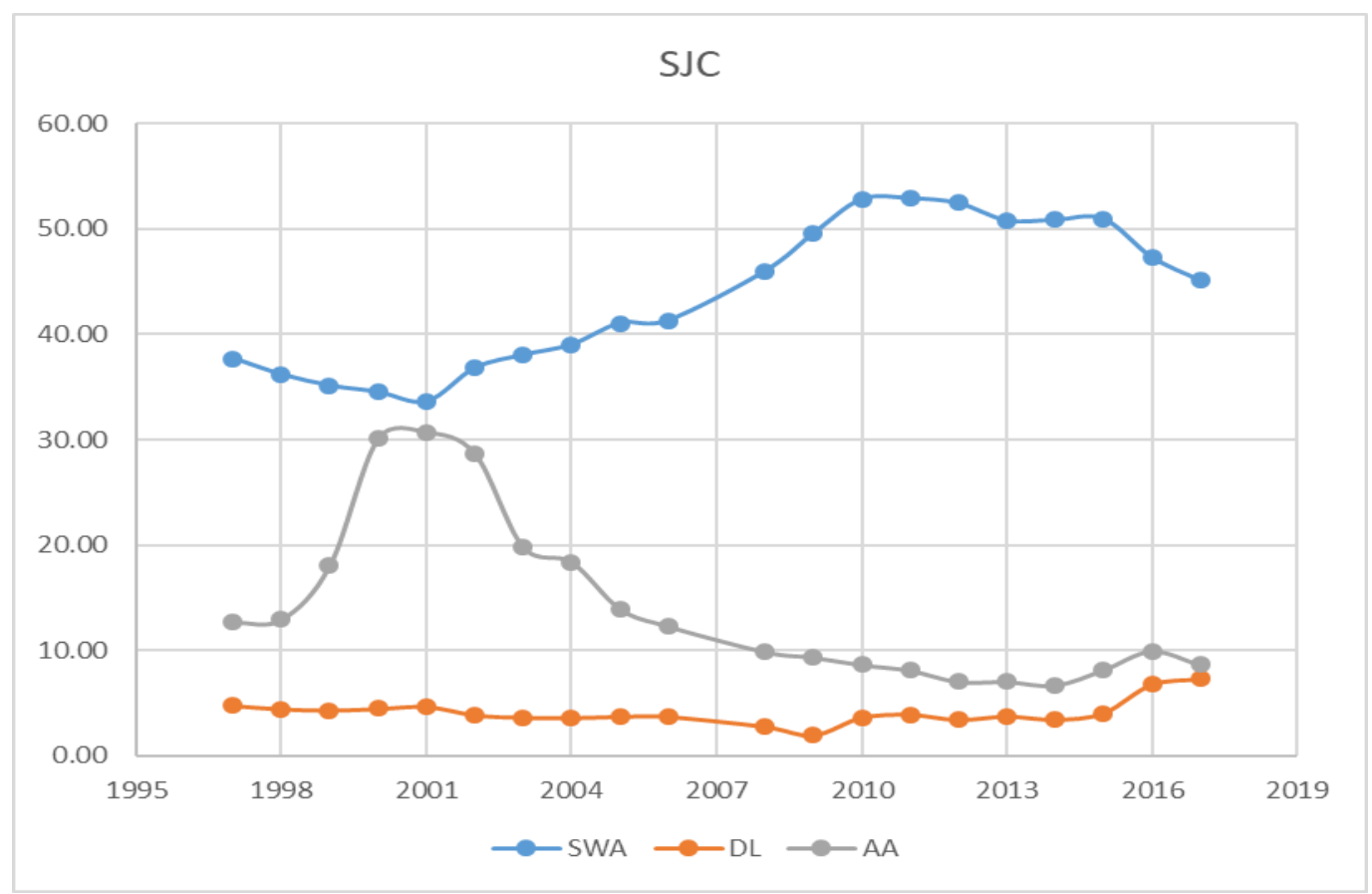

Figure 6. The Airlines' Market Share Development at SJC from 1997 to 2017 


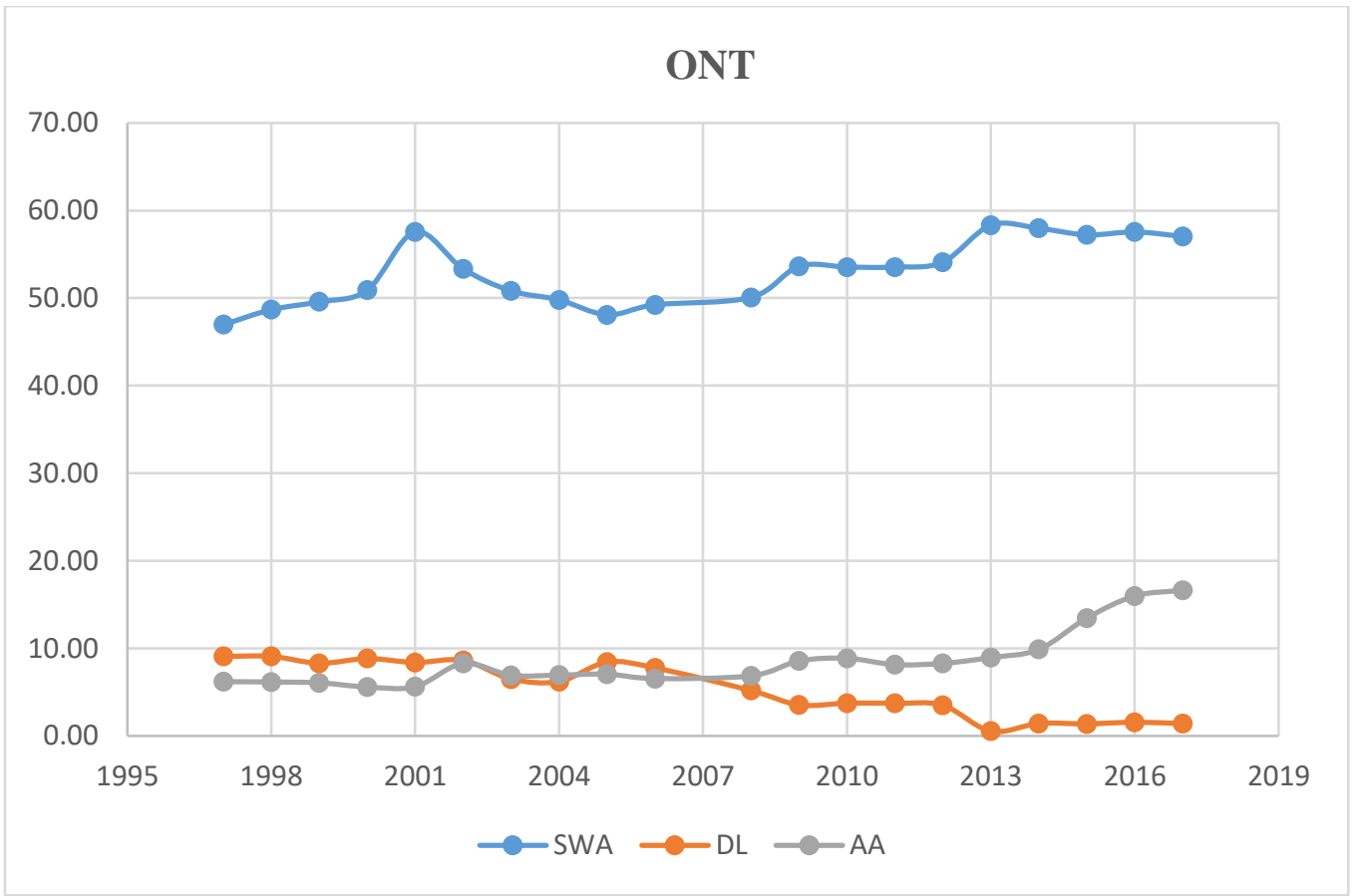

Figure 7. The Airlines' Market Share Development at ONT from 1997 to 2017

Figure 7 illustrates SWA, DL, and AA's market shares at ONT between 1997 and 2017. Overall, SWA and AA's proportion of market shares steadily increased at ONT, whereas DL's market shares steadily decreased over the period from 1997 through 2017.

\section{Discussion}

The data analysis portion of this study utilized a chi-square test for two categorical variables. This test indicated that the P-value $(0.0001)$ was less than the significance level (0.05). Based on this finding, the null hypothesis, which stated that there is no significant difference between LCCs' market share of passenger enplanements under the old business model and their market share of passenger enplanements under the new business model was rejected. In addition, the analysis of the descriptive data collected on passenger enplanements at the five secondary airports served by SWA suggested that a combination of factors, including an increase in population, employment, and personal incomes, may have contributed to the significant result of the chi-square test.

While the results provided by the chi-square test were significant and rejected the null hypothesis, socioeconomic and demographic factors, as well as other airlines' market shares in the same secondary service areas helped the author glean additional understanding of why this test was significant. This analysis 
suggested that the distributions for socioeconomic and demographic factors were almost identical and followed the same trend as that of SWA's market share increases under the new business model. More specifically, the research suggested that there was a positive relationship between SWA's market share increases and socioeconomic and demographic factors in the service areas of the secondary airports. For example, the population of all five cities in the secondary airport service areas saw a steady increase from 1997 till 2017. Similarly, SWA's employment numbers and the U.S. personal income increased steadily over the period from 1997 through 2017. These trends are comparable to the increases in SWA's market share of passenger enplanements while operating under the new business model.

Moreover, a comparative market share analysis suggested that SWA's new business model has led to competitive pressure on SWA's competitors, and an opportunity to improve SWA's competitive position at the secondary airports since 2007. For instance, SWA's market share of passenger enplanements at SJC rapidly increased after 2007, while other airlines' market share of passenger enplanements at SJC remained the same over the period from 2007 to 2017 . This may imply that LCCs are strengthening their competitive position for passenger traffic at U.S. secondary airports. The possible reason that has been given for this development is the LCC business model evolution.

Succinctly, since the chi-square analysis was significant, it is suggested that the increase in the market share analysis of the data was significant as well. Overall, the findings in the current study suggested that the chance to gain more market share for LCCs was especially higher after 2007 as LCCs evolved their business models.

\section{Recommendations and Conclusions}

Based on the results of this study, there are several opportunities where future research could expand upon the body of knowledge of LCCs business models. The research outlined in this document used LCCs' market data that exist in T-100 report. Future research should examine a broader spectrum of variables, such as seating density and aircraft utilization rates that can more realistically determine the impacts of the evolving LCCs business model. Most of the publications on the impacts of LCCs' business models to date have a focused-on Europe. Thus, the findings in such studies cannot be generalized to all LLC business models on the market shares of passenger enplanements at secondary airports in the U.S. Another suggestion for future study would be a focus on different geographic areas, such as the Asia and Pacific regions. Future research should also involve an in-depth case analysis of the overall trend in LCC business models. Such studies might provide more abundant data on the effect of changes in LCCs' business 
models on their market share of passenger enplanements at secondary airports. Lastly, further research should examine the financial and economic implications of the LCC business model evolution as compared to LCCs' revenues under the old and new business models.

The purpose of this paper was to examine what effect, if any, exists between LCCs' business models and their market share of passenger enplanements at secondary airports in the U.S. between the years of 1997 and 2017. By analyzing the data derived from BTS on five secondary airports, this research established possible influences of LCCs' new business model on their market share of passenger enplanements at U.S secondary airports. In this regard, the differences between LCCs' business models were significant and suggested that LCCs' market share of passenger enplanements at U.S. secondary airports started to grow after 2007. 


\section{References}

Abda, M. B., Belobaba, P. P., \& Swelbar, W. S. (2012). Impacts of LCC growth on domestic traffic and fares at largest US airports. Journal of Air Transport Management, 18(1), 21-25.

Acar, A. Z., \& Karabulak, S. (2015). Competition between full-service network carriers and low-cost carriers in Turkish Airline market. Procedia-Social and Behavioral Sciences, 207, 642-651.

Ary, D., Jacobs, L. C., Razavieh, A., \& Sorensen, C. K. (2010). Introduction to research in education (8th ed.). Belmont, CA: Wadsworth Cengage Learning.

Asahi, R., \& Murakami, H. (2017). Effects of Southwest Airlines' entry and airport dominance. Journal of Air Transport Management, 64, 86-90.

Ashiabor, S. Y., \& Wei, W. (2012). Development challenges of secondary and small airports in California. Mineta Transportation Institute, College of Business, San José State University.

Bachwich, A. R., \& Wittman, M. D. (2017). The emergence and effects of the ultra-low-cost carrier (ULCC) business model in the US airline industry. Journal of Air Transport Management, 62, 155-164.

Bentley, D. J. (2008). Low-cost airports terminal report edition 1. Sydney, Australia: Centre for Asia Pacific Aviation.

Beria, P., Laurino, A., \& Postorino, M. (2017). Low-cost carriers and airports: A complex relationship. In The Economics of Airport Operations (pp. 361386). Emerald Publishing.

Brueckner, J. K., Lee, D. N., Picard, P. M., \& Singer, E. (2015). Product unbundling in the travel industry: The economics of airline bag fees. Journal of Economics \& Management Strategy, 24(3), 457484.

Boeing. (2017, June 19). Current market outlook 2017-2036. Retrieved from http://www.boeing.com/resources/boeingdotcom/commercial/market/curre nt-market-outlook-2017/assets/downloads/2017-cmo-6-19.pdf

Bonnefoy, P. A. (2005). Emergence of secondary airports and dynamics of regional airport systems in the United States (Doctoral dissertation, Massachusetts Institute of Technology).

Bonnefoy, P. A. (2008). Scalability of the air transportation system and development of multi-airport systems: A worldwide perspective (Doctoral dissertation, Massachusetts Institute of Technology.)

Bureau of the Census. (2017a). U.S. Census Bureau-historical income tables. Retrieved from https://www.census.gov/data/tables/timeseries/demo/income-poverty/historical-income-people.html

Bureau of the Census. (2017b). U.S. Census Bureau-population and housing estimates. Retrieved from https://www.census.gov/programssurveys/popest.html 
Bureau of Transportation Statistics. (2016, November 15). History of BTS. Retrieved from https://www.bts.dot.gov/learn-about-bts-and-our work/history-bts

Bureau of Transportation Statistics. (2017). Data- airline employment. Retrieved from https://www.transtats.bts.gov/Employment/

Cento, A. (2008). The airline industry: Challenges in the 21st century. Heidelberg, Germany: Springer.

Choo, Y. Y., \& Oum, T. H. (2013). Impacts of low-cost carrier services on the efficiency of the major US airports. Journal of Air Transport Management, 33, 60-67.

Cheung, J. (2004). Airline competition and operating strategy in multi-airport systems. Cambridge, MA: Massachusetts Institute of Technology.

de Neufville, R. (2006). Accommodating low cost airlines at main airports. Transportation Research Board. Retrieved From http://ardent.mit.edu/airports/ASP_papers/Accommodating\%20Low\%20C ost\%20Carriers--\%20revised.pdf

de Neufville, R., \& Odoni, A. (2013). Airport systems, planning, design and management. New York, NY: McGraw-Hill.

de Wit, J. G., \& Zuidberg, J. (2012). The growth limits of the low-cost carrier model. Journal of Air Transport Management, 21, 17-23.

Diaconu, L., \& Popescu, C., C. (2011). The evolution of the low-cost airlines in the US. The case study on Southwest and JetBlue Airlines. The Annals of The "Ştefan cel Mare" University of Suceava. Fascicle of The Faculty of Economics and Public Administration, 92-97.

Dobruszkes, F., Givoni, M., \& Vowles, T. (2017). Hello major airports, goodbye regional airports? Recent changes in European and US low-cost airline airport choice. Journal of Air Transport Management, 59, 50-62.

Doganis, R. (2006). The airline business. London: Routledge.

Doganis, R. (2010). Flying off course IV: Airline economics and marketing. New York, NY: Routledge.

Dziedzic, M., \& Warnock-Smith, D. (2016). The role of secondary airports for today's low-cost carrier business models: The European case. Research in Transportation Business \& Management, 21,19-32.

Fageda, X., Suau-Sanchez, P., \& Mason, K. J. (2015). The evolving low-business model: Network implications of fare bundling and connecting flights in Europe. Journal of Air Transport Management, 42, 289-296.

Field, S. (2016). Southwest Airlines and the impact of low-cost carriers on airline ticket prices. The Bentley Undergraduate Research Journal, 36-58.

Garriga, J. C. (2003, May). Airport dynamics: Towards airport systems. Airport Regions Conference. Retrieved from http://www.aerohabitat.eu/ uploads/media/16-01-2007-ARC_Airport_Dynamics.pdf 
Graham, A. (2013). Understanding the low-cost carrier and airport relationship: A critical analysis of the salient issues. Tourism Management, 36, 66-76.

Gillen, D., \& Lall, A. (2004). Competitive advantage of low-cost carriers: some implications for airports. Journal of Air Transport Management, 10(1), 41-50.

Holloway, S. (2008). Straight and level: Practical airline economics. New York, NY: Ashgate.

International Civil Aviation Organization. (2017, June 13). List of low-costcarriers (LCCs). Retrieved from https://www.icao.int/sustainability/ Documents/LCC-List.pdf

Jankiewicz, J., \& Huderek-Glapska, S. (2016). The air transport market in Central and Eastern Europe after a decade of liberalization-Different paths of growth. Journal of Transport Geography, 50, 45-56.

Jimenez, E., Claro, J., de Sousa, J. P., \& de Neufville, R. (2017). Dynamic evolution of European airport systems in the context of low-cost carriers growth. Journal of Air Transport Management, 64, 68-76.

Lin, E., Mak, B., \& Wong, K. (2013). The business relationships between LCCs and airports in Southeast Asia: Influences of power imbalance and mutual dependence. Transportation Research Part A: Policy and Practice, 50, 3346.

Lordan, O. (2014). Study of the full-service and low-cost carriers' network configuration. Journal of Industrial Engineering and Management, 7(5), 1112.

Morrison, J., Bonnefoy, P., Hansman, R. J., \& Sgouridis, S. (2010, September). Investigation of the impacts of effective fuel cost increase on the us air transportation network and fleet. In 10th AIAA Aviation Technology, Integration, and Operations (ATIO) Conference, Fort Worth, TX.

McMullen, B. S., \& Du, Y. (2007). The economic impact of the ATA/Southwest airlines code share alliance. In Transportation Research Forum, 48th Annual Forum: 2007.

Michael, R. S. (2001). Crosstabulation \& chi square. Retrieved from http://www.indiana.edu/ educy520/sec6342/week_10/chi_sq_summary01 1020.pdf

Rey, B., Myro, R. L., \& Galera, A. (2011). Effect of low-cost airlines on tourism in Spain. A dynamic panel data model. Journal of Air Transport Management, 17(3), 163-67.

Silk, R. (2017, August 22). So-called 'Southwest Effect' alive and well. The Travel Weekly. Retrieved from http://www.travelweekly.com/TravelNews/Airline-News/So-called Southwest Effect-alive-well

Sorensen, J. (2005). European travelers get the point: low cost carriers add 
frequent flier benefits. Industry Analysis from Idea Works. Retrieved from https://www.ideaworkscompany.com/wp-content/uploads/2012/05/ AnalysisEuroLCCFrequentFlier.pdf

Spitz, W., O’Connor, M., Mills, R., Carroll, M., \& Murray, S. (2015). Effects of airline industry changes on small-and non-hub airports (No. Project 0329).

Štimac, I., Vince, D., \& Vidović, A. (2012, January). Effect of economic crisis on the changes of low-cost carrier's business models. In 15th International Conference on Transport Science ICTS 2012.

Strickland, J. (2015). Current challenges and future prospects for EU secondary airports. Brussels: Policy Department B: Structural and Cohesion Policies.

Summers, B. (2017, August 22). Southwest wants to start working with more international airlines. Skift. Retrieved from https://skift.com/2016/08/19/southwest-wants-to-start-working-with-moreinternational-airlines/

Swamedia. (2017, October 17). City fact sheets. Retrieved from https://www.swamedia.com/channels/City-Fact-Sheets/pages/fact-sheets

Takebayashi, M. (2012). Managing the multiple airport system by coordinating short/long-haul flights. Journal of Air Transport Management, 22, 16-20.

Vasigh, B., Fleming, K., Tacker, T. (2013). Introduction to air transport economics: From theory to Applications (2nd ed.). Hampshire, England: Ashgate.

Wensveen, J. G., \& Leick, R. (2009). The long-haul low-cost carrier: A unique business model. Journal of Air Transport Management, 15(3), 127-133.

Williams, G. (2011). Comparing the economic and operating characteristics of charter and low-cost scheduled airlines. Retrieved from https://www.researchgate.net/publication/292834772_Comparing_the_eco nomic_and_operating_characteristics_of_charter_and_lowcost_scheduled_airlines

Wiltshire, J. (2017). Airport competition: Reality or myth? Journal of Air Transport Management, 67, 241-248.

Vowles, T. M. (2001). The "Southwest Effect" in multi-airport regions. Journal of Air Transport Management, 7(4), 251-258. 